\title{
Is the MENA banking sector competitive?
}

\author{
Hatem Elfeituri ${ }^{1}$ \\ ${ }^{1} \mathrm{PhD}$ in Accounting and Finance - University of Portsmouth, UK 2016; Lecturer in Accounting \\ and Finance, University of East London, UK; Lecturer in Accounting, University of Benghazi, \\ Libya; Contact details: University of East London, London, E16 2RD, UK. Email: \\ Hatem@uel.ac.uk, H.elfeituri@gmail.com

\section{Konstantinos Vergos ${ }^{2}$} \\ ${ }^{2} \mathrm{PhD}$ in Finance, Senior lecturer in Economic and Finance, Portsmouth Business School, \\ University of Portsmouth, Richmond Building Portland Street Portsmouth PO1 3DE UK Email: \\ konstantinos.vergos@port.ac.uk
}

\begin{abstract}
The purpose of this paper is to investigate the competitive conditions and revenue drivers of commercial banks in the MENA region in the context of Panzar-Rosse model. It is the first study of its kind that examines a large sample of MENA banks for an extensive period (1999-2012) during an era of political and economic unrest and transformation that include the the global financial crisis (2007-2009). Panel data analysis using fixed effects was employed in order to examine whether the competitive conditions in MENA banks is explained by monopoly, monopolistic competition or perfect competition. Findings show that MENA banks operate under monopolistic competition, and bank-specific variables show a positive impact on revenue. These findings indicate that policymakers should relax capital adequacy requirements to guarantee the stability of the financial system. They also raise a concern that commercial banks in the MENA economies tend to concentrate on traditional lending activities, where their competitive position may be eroded in the long run by the decreasing state role of Islamic banks and by mergers that are not empirically justified for MENA banks during this period.
\end{abstract}

JEL classification: G21 F30 G20

Keywords: Panzer and Rosse, Competition, Revenues, Deregulation, MENA

\section{Introduction and motivation}

The banking industry is a main driver of a country's economic welfare, stability and growth (Claessens [1]). The critical importance of banking for the growth of developed and developing countries is accepted both in theoretical and empirical studies (Levine [2]). The examination of the banking system of developed countries, however, is not very helpful in deriving conclusions for developing countries, due to differences between these two groups of countries in the structure of their financial sectors. Whereas numerous studies have examined the banking industry of developed countries, there is a scarcity of research papers that investigate whether bank profitability in developing countries is a result of a lack of competition, despite their increasing significance on a global scale. . $^{2}$ 
Developing countries are associated with weak, less developed institutional environments (La Porta et al. [3]), so their financial systems are mainly bank-based. These countries are unable to follow the sophisticated approaches intended for advanced economies, due to structural weaknesses in the form of the low quality of accountancy data, the lack of auditing companies, accounting or risk measurement practices or other differences (Gonzalez-Rodriguez [5]). For that reason, this study will initially examine whether revenues of the banking sector in the Middle East and North Africa (MENA) region are due to monopolistic conditions and help to derive significant conclusions about the viability of the financial sector-hitherto empirically unaccounted for in current literature whilst also significantly extending our understanding of competitiveness in developing countries. To examine it, we use the Panzar and Rosse [6] model.

The importance of this study is threefold. First, investigating competitive conditions of MENA banks is crucial not only in terms of policy implications to optimally structure the banking system of these countries but, most importantly, for the efficient allocation of funds and long-term sustainable development. If the increase in banking revenues is due to perfect competition, instead of operating in a monopoly, then banks are expected to finance their needs at a lower cost and accept more feasible projects that will boost economic growth in this area. Second, research into the competitiveness of the banking industry in MENA countries is not as common as research for Europe, USA and Canada. This paper is the first to cover 11 MENA countries for an extended and recent period (14 years) in the context of Panzar and Rosse, filling a significant gap in the research. Third, we examine if foreign ownership and state ownership have the effect, as suggested by liberalisation processes employed by regulators, to promote competition, thus extending previous research (Turk-Ariss [7]; Bikker et al. [8]). ${ }^{2}$ Finally, we investigate if capital adequacy and bank size, and other firm-level factors lead to increased revenues in the MENA region. ${ }^{3}$

The rest of the paper is organised as follows. "The hypotheses" section formulates the hypotheses that are examined in this study. "MENA banking industry" section discusses major developments in the banking sector of the examined countries. "Literature review" section provides an overview of related banking. "Data and methodology" section presents the sample and the methodology used, and "Empirical results" section describes the empirical results. The conclusion and policy implications are discussed in "Conclusion"' section.

\section{The hypotheses}

We investigate the validity of three hypotheses. First, we examine the hypothesis (H1) that commercial banks operating in MENA countries increase revenue due to monopolistic competition. To examine this hypothesis, we compute the $H$ value and use the Wald test in the Panzar-Rosse model. If $H$ value is larger than zero and smaller than unity whilst Wald test results indicate that $H=0$ and $H=1$ is rejected, then the hypothesis H1 is supported. Second, we test the hypothesis (H2) that commercial banks in MENA countries have more revenue if they decrease state control and increase foreign 
stake. To examine this hypothesis, we compute the significance and magnitude of coefficients of state. If our hypothesis is correct, this should support the assumption of Shleifer and Vishny [11] and Shleifer [12] that state firms are inefficient due to government policies that transfer resources for political reasons. Third, we test the hypothesis $(\mathrm{H} 3)$ that commercial banks in MENA countries have more revenue are affected by bank-specific variables.

\section{MENA banking industry}

The MENA region has been considered to be one of the world's most troubled regions, especially since 1945. It consists of 17 countries, all of which, with the exception of Lebanon, have mainly Muslim populations (Lowe [13]). A number of MENA economies (Egypt, Tunisia, Morocco and Jordan among others) have launched economic reforms during the last 35 years and witnessed the liberalisation of their financial systems (TurkAriss [7]; Naceur and Omran [14]). Development of the banking sectors in the MENA countries differs from one country to another. The oil-rich countries of the Gulf Cooperation Council (GCC) $)^{4}$ cover a region where the process of financial liberalisation and deregulation have been accelerated as part of the GCC plan to transform its members from oil-based economies to market-based. According to the IMF [15], the hydrocarbon exports of these countries account for approximately $50 \%$ of the region's GDP. As a result of increasing oil prices, GDP growth in 2003-2007 accelerated to $6.5 \%$, significantly higher than its previous 4\%. However, the global financial crisis of 2008 and its consequences, as well as the 2010 Arab uprising negatively influenced these economies with real GDP slowing down since then. On the other hand, despite the country's economic importance, the financial sector in Egypt is less developed when compared to those of GCC economies (Omran [16]). Whereas many banks in Egypt are family-owned, the state controls most of the specialised banks in the country (Neceur et al. [17]). Nevertheless, since the banking law in Egypt was enacted in 1975 (Central Bank of Egypt [18]), significant merger and acquisitions activity has taken place, particularly since 2005, resulting in increased foreign participation and a decreased role for the state. Lebanon has a more modern banking sector, compared with Egypt, and from 1995, the bank liquidity and capital adequacy in Lebanon have been in line with Bank for International Settlements (BIS) standards (Naceur and Kandil [19]). Finally, Jordanian national currency depreciated after the 1988-1989 crises, forcing the government to ask the International Monetary Fund (IMF) for help. The Jordanian government subsequently introduced a stabilisation programme, leading to privatisation, restructuring the financial sector (Bdour and Al-khoury [20]), whilst also removing, in 1997, the maximum limit of foreign direct investments. According to the 2000 banking law [37], the country's banks are required to comply, inter alia, with a number of conditions in terms of registration and license fees, while also offering financial consulting and investment portfolio services. 


\section{Literature review}

Whereas structural approaches examine whether market concentration reduces competitive conditions in a market by adopting collusive behaviour among enterprises (Berger [21]; Bikker and Bos [22]), non-structural paradigms examine factors, other than structure and concentration, which influence market competition. The Panzar and Rosse [6] model applied in this study belongs to the latter approach and estimates equations that assume revenue is a function of input prices and other variables. By computing the summation of elasticity of revenues to input prices, also called $\mathrm{H}$-statistic, we make conclusions about equilibrium conditions, as described in Table 3. The competitive environment is considered to be monopolistic competition when the H-statistic takes a value between zero and the unity, whilst it is regarded as perfectly competitive if the $\mathrm{H}$ statistic is equal to one (Panzar and Rosse [6]).

In the long run, in a competitive equilibrium, total revenues increase whenever input prices increase. A bank that is unable to anticipate input price hikes, will exit the sector, while the banks that remain in the market will face increasing demand that will lead to increasing output prices and revenues in the same proportion as cost. In that way, the $\mathrm{H}$ statistic is equal to one (Gunalp and Celik [23]; Turk-Ariss [7]; Claessens [1]).

The Panzar and Rosse model has been adopted by numerous studies in both developed and developing economies (Turk-Ariss [7]; Molyneux et al. [9]; Mamatzakis [10]).. Early studies in developed markets found mixed results regarding competitive conditions. Canadian banks, trust companies and mortgage companies (Nathan and Neave [24]), and banks in Germany, the United Kingdom, Italy, France and Spain (Molyneux et al. [9]) operated under monopolistic competition, whilst Molyneux et al. [25] provide evidence that commercial banks in Japan were operating under a monopoly in 1986 which developed into monopolistic competition in 1988. De Rozas [26] provides evidence that the Spanish banking sector is more competitive among larger banks and found increasing competition in the $1980 \mathrm{~s}$, attributed to liberalisation. A growing body of literature has also been focused on emerging markets. Mamatzakis et al. [10] assessed whether structural reforms made the banking industry in central and Eastern Europe more competitive and found that with the exception of Latvia, they operated under monopolistic competition. Gunalp and Celik [23] examined banks in Turkey during $1990 \mathrm{~s}$ and their findings suggest that Turkish banks gained their revenue under monopolistic competition and that they were positively influenced by liberalisation and deregulation measures. In the same context, the IMF [15] estimated the degree of bank competition for UK, USA and Eurozone economies and found that competition converged after the introduction of the European monetary union, whilst the 2008 financial crisis resulted in declining competition in several countries, in particular where large credit and housing booms had headed the crisis. Olivero and Jeon [27] investigated how competition in banking affected the effectiveness of the monetary policy transmission mechanism in selected emerging Asian and Latin American countries between 1996 and 2006. By applying the methodology proposed by Panzar and Rosse [6], they concluded that the banking sectors in Latin America and Asia are categorised as monopolistically competitive. Additionally, the level of competition in Angola's banking 
industry was assessed by Barros and Mendes [28] using the Panzar-Rosse model over the period 2005 to 2014. Results confirm that the Angolan banking sector operates under monopolist competition. After examining the banking system in Uganda, Hauner and Peiris[29] concluded that large banks and foreign-owned banks perform more efficiently than others, whereas the efficiency of small banks has dropped with the increase in competitive pressure.

A limited number of studies have examined MENA region banks. Murjan and Ruza [30] used the Panzar and Rosse model to examine the dominant competitive conditions of banks from nine Arab Middle Eastern countries, during the period 1993-1997. They found that the banking sector in that region had been operating under conditions of monopolistic competition. Evidence of the degree of competition using P-R methodology on the MENA banking sector is extended in Turk-Ariss [7] who investigated the degree of market power and competitiveness of 12 banking markets in MENA, finding that, with the exception of North African countries, banks in the region operate under monopolistic competition. Polemis [31] assessed the level of banking competition in eight MENA economies over the period 1997-2012 and confirmed evidence in favour of a monopolistically competitive industry, in line with Turk-Ariss [7].

\section{Data and methodology}

\section{Data}

In this paper we examine 149 banks from 11 MENA countries, in particular Bahrain, Egypt, Jordan, Kuwait, Lebanon, Morocco, Oman, Qatar, Saudi Arabia, Tunisia and the United Arab Emirates (UAE) during the period 1999-2012, Kuwait having the smallest number of operating banks (5) and Lebanon the largest (35). We use Bankscope database as the source of study data. We include all the banks, under the condition operating for at least 3 years during the period examined. Table 1lists the number of banks by country and by their ownership characteristics.

\section{Table 1 Number of banks in the sample}

\begin{tabular}{llll}
\hline Country & Total number of banks & Domestic banks & Foreign banks \\
\hline Bahrain & 10 & 7 & 3 \\
Kuwait & 5 & 5 & 0 \\
Oman & 6 & 2 & 4 \\
Qatar & 7 & 6 & 1 \\
Saudi Arabia & 8 & 8 & 0 \\
United Arab Emirates & 18 & 15 & 3 \\
Egypt & 23 & 11 & 12 \\
Jordan & 11 & 9 & 2 \\
\hline
\end{tabular}




\begin{tabular}{llll}
\hline Lebanon & 35 & 30 & 5 \\
Morocco & 13 & 9 & 4 \\
Tunisia & 13 & 7 & 6 \\
Total & 149 & 109 & 40 \\
\hline
\end{tabular}

Statistics describing the main variables used in our analysis are illustrated in Table 2. We report average values and standard deviation (in brackets) for the full sample of MENA economies over the study period (1999-2012). Bank profitability and bank revenues in higher-income economies, namely in UAE, Qatar, Saudi Arabia, Kuwait, Oman and Bahrain, are above the average profitability of banks in the area, whereas bank profitability in low-income MENA economies such as Egypt, Tunisia, Lebanon and Morocco is below the average.

Table 2 Descriptive statistics for selected bank profitability and revenue variables (average 1999-2012)

\begin{tabular}{llllllll}
\hline $\begin{array}{l}\text { Variable } \\
\text { Country }\end{array}$ & ROA & TR/TA & II/TA & EQAS & SIZE & LOANAST & SECAST \\
\hline Bahrain & 1.04 & 0.031 & 0.023 & 11.04 & 1172 & 44.31 & 0.250 \\
& $(1.15)$ & $(0.023)$ & $(0.022)$ & $(2.76)$ & $(1010)$ & $(12.78)$ & $(0.13)$ \\
Oman & 1.89 & 0.077 & 0.064 & 12.97 & 390 & 69.44 & 0.101 \\
& $(1.28)$ & $(0.046)$ & $(0.046)$ & $(2.24)$ & $(416)$ & $(7.97)$ & $(0.061)$ \\
Qatar & 2.46 & 0.030 & $(0.017$ & 13.90 & 1123 & 57.26 & 0.206 \\
& $(1.13)$ & $(0.023)$ & $(0.021)$ & $(3.63)$ & $(1810)$ & $(6.99)$ & $(0.163)$ \\
Saudi & 2.23 & 0.045 & 0.032 & 12.18 & 2290 & 50.78 & 0.308 \\
Arabia & $(1.58)$ & $(0.016)$ & $(0.008)$ & $(3.11)$ & $(1741)$ & $(9.62)$ & $(0.094)$ \\
UAE & 2.48 & 0.075 & .060 & 17.11 & 1251 & 61.74 & 0.076 \\
& $(1.55)$ & $(0.051)$ & $(0.050)$ & $(5.630)$ & $(1890)$ & $(11.14)$ & $(0.058)$ \\
Kuwait & 1.86 & 0.055 & 0.043 & 12.19 & 1420 & 54.68 & 0.233 \\
& $(1.52)$ & $(0.025)$ & $(0.024)$ & $(2.70)$ & $(1207)$ & $(10.93)$ & $(0.108)$ \\
Egypt & 0.89 & 0.068 & 0.051 & 9.60 & 576 & 39.87 & 0.252 \\
& $(1.72)$ & $(0.029)$ & $(0.024)$ & $(4.79)$ & $(932)$ & $(11.96)$ & $(0.120)$ \\
Jordan & 1.23 & 0.031 & 0.016 & 11.77 & 858 & 44.01 & 0.176 \\
& $(1.06)$ & $(0.011)$ & $(0.010)$ & $(6.42)$ & $(1280)$ & $(7.41)$ & $(0.072)$ \\
Lebanon & 0.76 & 0.068 & 0.059 & 8.94 & 340 & 26.40 & 0.351 \\
& $(0.846)$ & $(0.035)$ & $(0.030)$ & $(4.52)$ & $(489)$ & $(8.69)$ & $(0.120)$ \\
Morocco & 0.79 & 0.215 & 0.206 & 7.85 & 1200 & 45.90 & 1.12 \\
Tunisia & $(1.18)$ & $(1.28)$ & $(1.28)$ & $(2.99)$ & $(1030)$ & $(20.10)$ & $(7.63)$ \\
& 0.30 & 0.044 & 0.026 & 11.54 & 185 & 62.67 & 0.074 \\
\hline In para)
\end{tabular}

In parentheses the standard deviation

Table 2 also indicates that Omani commercial banks, followed by UAE banks rely heavily on interest income affecting total revenue to assets (TR/TA) and Interest Income to Total Assets (II/TA). The capitalisation of commercial banks also differs depending on the country. Whilst the average ratio of equity to assets (EQAS) of banks in the MENA region in our sample that operate in Bahrain, Oman, Saudi Arabia, UAE, Kuwait 
and Qatar are better capitalised than banks in other MENA countries probably due to regulatory interventions. High capitalisation ratios indicate that banks have the capacity to expand lending without the need to raise capital (Mamatzakis et al. [10]).

\section{Methodology}

The H-statistic has been developed to discriminate between monopolistic, perfectly competitive and monopolistically competitive markets (Panzar and Rosse [6]), based on a general banking model that determines revenue $T R$ for a financial institution by multiplying profit-maximising quantity and price. Molyneux et al. [9] argue that $\mathrm{H}$ statistic values can be anywhere between minus infinity and unity. If the H-statistic is negative, the banking market is characterised as monopoly, and increasing prices will eventually decrease output (Mamatzakis et al. [10]). The equilibrium test in the Panzar and Rosse model is calculated as the sum of input prices elasticities with the return on average assets (ROA). If the hypothesis that the value of $\mathrm{H}$-statistic is zero is tested and not rejected, this would imply equilibrium conditions. Table 3 summarises the discriminatory power of the $\mathrm{H}$-statistic.

\section{Table 3. The discriminatory power of $\mathbf{H}$}

\begin{tabular}{c|l}
\hline Values of $\mathbf{H}$ & Competitive environment \\
\hline $\mathrm{H} \leq 0$ & $\begin{array}{l}\text { Monopoly: } \mathrm{H} \text { is a decreasing function of the perceived demand elasticity. Banks operate under } \\
\text { monopolistic profit maximisation conditions. }\end{array}$ \\
$\infty<H<1$ & $\begin{array}{l}\text { Monopolistic competition. } \mathrm{H} \text { is an increasing function of the perceived demand elasticity. } \\
\mathrm{H}=1\end{array}$ \\
\hline
\end{tabular}

Source: Bikker and Haaf (2002)

There are a number of assumptions (Nathan and Neave [24]; Molyneux et al. [25]) that need to be considered in order to implement the Panzar-Rosse model in the current study. The first of these assumptions is widely used in banking literature: banks in the market have to be treated as single-product firms, as banks can use their labour, capital, deposits and short-term funding as inputs in generating interest revenues. Second, it has to be taken into account that higher-quality services are not related to higher input prices that generate higher revenues because the bias of the $\mathrm{H}$-statistic may result from this correlation. Third, one needs to assume that the economic environment for this study can be unpredictable or unstable; hence, to overcome this issue, panel data analysis should be used. Nevertheless, as noted by Mamatzakis et al. [10], the Panzar and Rosse approach enjoys simplicity and transparency, without a decline in efficiency. In addition, data availability problems are reduced because revenue data tend to be more noticeable than output prices, enabling an investigation at a bank level, and decreasing misspecification of market restrictions, and thus, it is suitable for examining banking in MENA economies. 
Following Nathan and Neave [24] Molyneux et al. [9], Mamatzakis et al. [10], and TurkAriss [7], the current study estimates two measures of revenue (total revenue to total assets (TR/TA) and interest revenue to average total assets (II/TA), which are explained by factor prices and other bank-specific variables for commercial banks in 11 MENA economies over the period 1999-2012 using panel data:

$$
\begin{aligned}
& \operatorname{LnTR} / \mathrm{T} A_{i t}= \\
& a_{0}+\beta_{1} \operatorname{lnPF}_{i t}+\beta_{2} \ln P L_{i t}+\beta_{3} \ln P K_{i t}+\delta_{1} \operatorname{lnSIZE_{it}}+\gamma_{1} \operatorname{lnSECAST} \mathrm{T}_{i t}+ \\
& \gamma_{2} \operatorname{lnEQAS} \text { it }_{1}+\gamma_{3} \operatorname{lnLOANAST}{ }_{i t} \delta_{2} \text { FORE }+\delta_{3} S T A T E+\delta_{4} \text { COUNTRY }+\delta_{5} Y E A R+\varepsilon
\end{aligned}
$$

Where TR/TA is total revenue computed as the summation of interest income and noninterest income divided by total assets as in Molyneux et al. [25] and Turk-Ariss [7] who argued that as most of modern commercial banks increasingly rely on fee-related banking and financial services as well as providing loans, we should take account of feebased activities and not only interest-based activities. Nevertheless, interest revenue (II/TA) is also used to represent the version that has been used inter alia by Molyneux et al. [25]

$$
\begin{aligned}
& \operatorname{LnII} / \mathrm{T} A_{i t}= \\
& a_{0}+\beta_{1} \ln P F_{i t}+\beta_{2} \ln P L_{i t}+\beta_{3} \ln P K_{i t}+\delta_{1} \operatorname{lnSIZE} E_{i t}+\gamma_{1} \operatorname{lnSECAST} T_{i t}+ \\
& \gamma_{2} \operatorname{lnEQAS} \text { it }_{i t}+\gamma_{3} \operatorname{lnLOANAST} \text { it }+\delta_{2} \text { FORE }+\delta_{3} \text { STATE }+\delta_{4} \text { COUNTRY }+\delta_{5} \text { YEAR + }
\end{aligned}
$$

PF represents the unit price of funds, proxied by interest expenses over total deposits; PL is the unit price of labour, as the ratio of staff expenses over total assets; ${ }^{-}$PK denotes the unit price of capital expenditure and other expenses to fixed assets to include equipment ATMs computers, premises, advertisement and other non-interest expenses (Molyneux et al. [9]; Gunalp and Celik [23]). The unit prices of PF, PK and PL which are funds, capital and labour, respectively, are the proxies of these prices of commercial banks in the MENA economies. In the notation of Eqs. (1), (2) and (3), H-statistic is the summation of $\left(\beta_{1}+\beta_{2}+\beta_{3}\right)$.

This paper use two variables to account for bank-specific risk, namely total equity to assets ratio (EQAS) and loans to assets ratio (LOANAST). We expect better capitalised banks and banks that allocate a larger proportion of assets to loans to be more profitable, the latter because a larger proportion of loans is associated with more risk and return (Molyneux et al. [9]; Gunalp and Celik [23]). Size provides indication for possible economies of scale. The securities to total assets ratio (SECAST) is a proxy of profitbearing assets .However, investing too much in securities at the expense of issuing loans may decrease bank profitability. To investigate whether state and foreign ownership have an impact on bank revenue, we include a dummy variable that accounts for state control and foreign ownership, respectively. In particular, we categorise a bank as a state-owned bank if the government ownership is larger than 50\%. Similarly, if the majority (more 
than $50 \%$ ) of a bank's shares belong to foreign investors, we consider the bank to be foreign owned. Table 4 summarises the definitions of variables used in assessing the competition of commercial banks and equilibrium tests.

Table 4. Definitions of variables used in assessing the competition of commercial banks and equilibrium tests.

\begin{tabular}{|c|c|}
\hline Variable & Description \\
\hline $\mathrm{Ln}$ & Natural Logarithm \\
\hline TR/TA & $\begin{array}{l}\text { Total revenue to total assets. Total revenues include revenues generated from loans and } \\
\text { advances as well as other interest income containing interest from long term claims, } \\
\text { government securities, commissions, and others }\end{array}$ \\
\hline II/TA & Interest income to total assets \\
\hline ROA & $\begin{array}{l}\text { Return on average assets is the return generated from the assets financed by the bank. (net } \\
\text { profit over average total assets) }\end{array}$ \\
\hline PF & $\begin{array}{l}\text { The unit price of funds proxied by the ratio of interest expense to total deposits. Interest } \\
\text { expense includes interest paid on deposits and commissions expense and payments. }\end{array}$ \\
\hline PL & $\begin{array}{l}\text { The unit price of labour proxied by the ratio of personnel expenses to the total assets. } \\
\text { Personnel expenses include wages and salaries, social security contributions, contribution to } \\
\text { pension funds and others. }\end{array}$ \\
\hline PK & $\begin{array}{l}\text { The unit price of capital expenditure and other expenses to fixed assets. Capital expenses refer } \\
\text { to costs spending on fixed assets. Fixed assets include tangible assets fixed assets (land, } \\
\text { buildings and installations, furniture office, computers, ATMs, technological items) and } \\
\text { intangible fixed assets (such as goodwill, software, research and development expenses, etc). }\end{array}$ \\
\hline SIZE & $\begin{array}{l}\text { Total assets represent a proxy for bank size including earning assets }+ \text { cash and due from } \\
\text { banks }+ \text { foreclosed real estate }+ \text { fixed assets }+ \text { goodwill. }\end{array}$ \\
\hline SECAST & $\begin{array}{l}\text { Total securities to total assets include loans and advances }+ \text { trading securities }+ \text { derivatives }+ \\
\text { available for the sale securities }+ \text { held to maturity securities }+ \text { equity investments } \\
+ \text { government bonds }+ \text { other securities. }\end{array}$ \\
\hline EQAS & $\begin{array}{l}\text { Equity to total assets. This variable is used to measure capital adequacy, computed as equity } \\
\text { to total assets. High capital-asset ratios indicate low leverage and therefore lower risks. }\end{array}$ \\
\hline LOANAST & $\begin{array}{l}\text { Net loans to total assets. This is a measure of liquidity computed as loans to total assets. } \\
\text { Higher ratios imply lower liquidity. }\end{array}$ \\
\hline FORE & Dummy variable for foreign ownership \\
\hline STATE & Dummy variable for state ownership \\
\hline
\end{tabular}

Source: Bankscope database

Following Molyneux et al. [9], Mamatzakis et al. [10] and Turk-Ariss [7], we investigate the long-term equilibrium conditions by examining whether the H-statisticis statistically different from zero, by using the following equation where the dependent variable is a return on total assets (ROA) as follows:
$\operatorname{LnROA}_{i t}=a_{0}+\beta_{1} \operatorname{lnPF} F_{i t}+\beta_{2} \operatorname{lnP} L_{i t}+\beta_{3} \ln P K_{i t}+\delta_{1} \operatorname{lnSIZE_{it}}+\gamma_{1} \operatorname{lnSECAST} \mathrm{T}_{i t}+$ $\gamma_{2} \operatorname{lnEQAS}$ it $_{i t}+\gamma_{3} \operatorname{lnLOANAST}{ }_{i t}+\delta_{2}$ FORE $+\delta_{3} S T A T E+\delta_{4}$ COUNTRY $+\delta_{5}$ YEAR + $\varepsilon \quad(3)$

This study uses unbalanced panel data to estimate the reduced-form revenue equation implied by the Panzar-Rosse model. We use fixed effects models to control for unobserved heterogeneity, and we examine the suitability of fixed effects versus random effects for this model based on a Hausman specification test, whilst also applying robust standard errors to correct heteroscedasticity as noted by Baltagi [32]. 


\section{Empirical results}

\section{Empirical results for Competitive conditions}

This part of the analysis examines competition (H-statistic) and individual factors using fixed effect models. We also account for country and time effects and competitive structure differences.

\section{Competition conditions}

Tables 5 and 6 report the regression results using total revenues (TR/TA) and interest income (II/TA) as a dependent variable, respectively. The regression coefficients for the sum of input price (PF, PK and PL) are all positive and significant at the $1 \%$ confidence level in Tables 5 and 6 . The coefficient of the price of fund, PF, is found positive and significant for all regressions in Table 6, implying that the higher the interest expenses are over short-term funds and deposits, the higher the revenues will be. Also, the price of capital (PK) and price of labour (PL) are positive and significant at the $1 \%$ level, indicating that an increasing price of labour and capital leads to increasing income, providing some indication of the importance of investments (e.g., to strengthen ATM networks) that become increasingly crucial in modern banking. These results are in line with findings in emerging markets as in Turkey (Gunalp and Celik [23]).

Table 5 Panzar and Rosse model competition results, using total revenue to average total assets as dependent variable

\begin{tabular}{|c|c|c|c|c|}
\hline & Fixed effect 1 & Fixed effect 2 & Fixed effect 3 & Fixed effect 4 \\
\hline \multirow[t]{2}{*}{ LnPF } & $0.162 * * *$ & $0.318 * * *$ & $0.240 * * *$ & $0.345^{* * *}$ \\
\hline & $(5.324)$ & (13.604) & (8.039) & (14.403) \\
\hline \multirow[t]{2}{*}{ LnPK } & $0.139 * * *$ & $0.125 * * *$ & $0.098 * * *$ & $0.098 * * *$ \\
\hline & $(5.848)$ & (5.120) & (4.047) & (3.946) \\
\hline \multirow[t]{2}{*}{ LnPL } & $0.433 * * *$ & $0.384 * * *$ & $0.394 * * *$ & $0.353 * * *$ \\
\hline & (13.134) & (11.460) & (11.756) & $(10.450)$ \\
\hline \multirow[t]{2}{*}{ LnSECAST } & $-0.021 * *$ & $-0.030 * *$ & -0.020 & $-0.027 *$ \\
\hline & $(-1.409)$ & $(-1.945)$ & $(-1.359)$ & $(-1.784)$ \\
\hline \multirow[t]{2}{*}{ LnSIZE } & 0.013 & $-0.093 * * *$ & -0.007 & $-0.074 * * *$ \\
\hline & $(0.689)$ & $(-6.032)$ & $(-0.454)$ & $(-4.923)$ \\
\hline \multirow[t]{2}{*}{ LnEQAS } & $0.058 * *$ & 0.029 & 0.046 & 0.040 \\
\hline & (1.964) & (0.989) & (1.528) & (1.300) \\
\hline \multirow[t]{2}{*}{ LnLOANAST } & $0.208 * * *$ & $0.168 * * *$ & $0.125 * * *$ & $0.133 * * *$ \\
\hline & $(5.648)$ & $(4.503)$ & $(3.462)$ & $(3.662)$ \\
\hline \multirow[t]{2}{*}{ FORE } & -0.038 & -0.099 & -0.011 & -0.091 \\
\hline & $(-0.591)$ & $(-1.475)$ & $(-0.185)$ & $(-1.405)$ \\
\hline \multirow[t]{2}{*}{ INTERCEPT } & $-1.990 * * *$ & -0.064 & $-0.710 * * *$ & 0.228 \\
\hline & $(-5.334)$ & $(-0.208)$ & $(-2.500)$ & $(0.895)$ \\
\hline YEAR & YFS & $\mathrm{NO}$ & YFS & $\mathrm{NO}$ \\
\hline EFFECTS & $1 \mathrm{LS}$ & 170 & 1 IS & 100 \\
\hline COUNTRY & YES & YES & NO & $\mathrm{NO}$ \\
\hline
\end{tabular}




\begin{tabular}{crrrr}
\hline EFFECTS & & & & \\
Adj-R $^{\mathbf{2}}$ & 0.65 & 0.63 & 0.59 & 0.58 \\
F-statistic & 19.45 & 19.39 & 16.60 & 17.03 \\
Prob(F-statistic) & 0.000 & 0.000 & 0.000 & 0.000 \\
Hausman Test & 0.000 & 0.000 & 0.000 & 0.000 \\
H-value & $\mathbf{0 . 7 3}$ & $\mathbf{0 . 8 3}$ & $\mathbf{0 . 7 3}$ & $\mathbf{0 . 8 0}$ \\
Wald test, H=0 & 256.1 & 342.2 & 260.4 & 324.5 \\
Prob & 0.00 & 0.00 & 0.00 & 0.00 \\
Wald test, H=1 & 33.27 & 14.69 & 34.22 & 20.81 \\
Prob & 0.00 & 0.00 & 0.00 & 0.00 \\
\hline
\end{tabular}

Dependent variable: $\mathrm{Ln}(\mathrm{TR} / \mathrm{TA}) . \mathrm{TR} / \mathrm{TA}=$ Total revenue to total assets, $\mathrm{PF}=$ price of fund (interest expense to deposits), $\mathrm{PK}=$ price of capital (non-interest expenses to fixed assets, $\mathrm{PL}=$ price of labour (personal expenses to total assets), SECAST $=$ securities to total assets, $\mathrm{SIZE}=$ Total assets, $\mathrm{EQAS}=$ equity to total assets, $\mathrm{LOANAST}=$ net loans to assets, $\mathrm{FORE}=$ dummy for foreign ownership, STATE= dummy for state ownership

*significant at the $10 \%$ level; **significant at the $5 \%$ level, and ***significant at the $1 \%$ level

Table 6 Panzar and Rosse model competition, using interest income to average total assets (II/TA) as dependent variable

\begin{tabular}{|c|c|c|c|c|c|}
\hline & Fixed effect 5 & Fixed effect 6 & Fixed effect 7 & Fixed effect 8 & Fixed effect 9 \\
\hline \multirow[t]{2}{*}{ LnPF } & $0.314 * * *$ & $0.457 * * *$ & $0.413 * * *$ & $0.495 * * *$ & $0.311 * * *$ \\
\hline & (6.957) & (13.333) & $(9.208)$ & $(13.871)$ & (7.008) \\
\hline \multirow[t]{2}{*}{ LnPK } & $0.117 * * *$ & $0.104 * * *$ & 0.057 & 0.059 & $0.112 * * *$ \\
\hline & (3.309) & (2.913) & $(1.580)$ & (1.617) & (3.178) \\
\hline \multirow[t]{2}{*}{ LnPL } & $0.440 * * *$ & $0.396 * * *$ & $0.382 * * *$ & $0.349 * * *$ & $0.440 * * *$ \\
\hline & $(9.002)$ & (8.086) & (7.598) & $(6.981)$ & $(9.161)$ \\
\hline \multirow[t]{2}{*}{ LnSECAST } & 0.004 & -0.000 & 0.007 & 0.005 & \\
\hline & $(0.187)$ & $(-0.029)$ & $(0.307)$ & $(0.243)$ & \\
\hline \multirow[t]{2}{*}{ LnSIZE } & 0.034 & $-0.086^{* * *}$ & -0.004 & $-0.075^{* * *}$ & 0.031 \\
\hline & (1.204) & $(-3.799)$ & $(-0.177)$ & $(-3.352)$ & (1.088) \\
\hline \multirow[t]{2}{*}{ LnEQAS } & 0.030 & -0.004 & 0.013 & 0.003 & \\
\hline & $(0.693)$ & $(-0.093)$ & $(0.297)$ & $(0.081)$ & \\
\hline \multirow[t]{2}{*}{ LnLOANAST } & $0.232 * * *$ & $0.197 * * *$ & $0.105^{*}$ & $0.119 * *$ & $0.228 * * *$ \\
\hline & $(4.262)$ & (3.617) & (1.947) & $(2.218)$ & (4.237) \\
\hline \multirow[t]{2}{*}{ FORE } & -0.025 & -0.093 & 0.018 & -0.059 & -0.021 \\
\hline & $(-0.259)$ & $(-0.949)$ & $(0.192)$ & $(-0.622)$ & $(-0.223)$ \\
\hline \multirow[t]{2}{*}{ STATE } & 0.100 & $0.162 *$ & -0.004 & 0.015 & 0.090 \\
\hline & (1.158) & $(1.872)$ & $(-0.051)$ & $(0.176)$ & $(1.081)$ \\
\hline \multirow[t]{2}{*}{ INTERCEPT } & $-2.163 * * *$ & 0.015 & -0.491 & 0.527 & $-2.039 * * *$ \\
\hline & $(-3.881)$ & $(0.0335)$ & $(-1.154)$ & (1.399) & $(-3.928)$ \\
\hline $\begin{array}{c}\text { YEAR } \\
\text { EFFECTS }\end{array}$ & YES & NO & YES & NO & YES \\
\hline $\begin{array}{l}\text { COUNTRY } \\
\text { EFFECTS }\end{array}$ & YES & YES & NO & NO & YES \\
\hline $\mathbf{R}^{2} \mathbf{A d j}$ & 0.64 & 0.62 & 0.61 & 0.56 & 0.64 \\
\hline
\end{tabular}




\begin{tabular}{cccccc}
\hline Hausman Test & 0.000 & 0.000 & 0.000 & 0.000 & 0.000 \\
H-value & $\mathbf{0 . 8 7}$ & $\mathbf{0 . 9 5}$ & $\mathbf{0 . 8 5}$ & $\mathbf{0 . 9 0}$ & $\mathbf{0 . 8 6}$ \\
Wald test, H=0 & 162.2 & 211.5 & 154.3 & 186.9 & 165.2 \\
Prob & 0.000 & 0.000 & 0.000 & 0.000 & 0.000 \\
Wald test, H=1 & 3.45 & 0.40 & 4.51 & 2.09 & 4.09 \\
Prob & 0.06 & 0.52 & 0.03 & 0.14 & 0.04 \\
\hline
\end{tabular}

Dependent variable: $\mathrm{Ln}(\mathrm{II} / \mathrm{TA})$. (II/TA)= Interest revenue to total assets. Independent variables $\mathrm{PF}=$ price of fund (interest expense to deposits), $\mathrm{PK}=$ price of capital (non-interest expenses to fixed assets, $\mathrm{PL}=$ price of labour (personal expenses to total assets), SECAST =securities to total assets, SIZE $=$ Total assets, EQAS= equity to total assets, LONAAST= net loans to assets, FORE= dummy for foreign ownership, STATE= dummy for state ownership.

*significant at the $10 \%$ level; **significant at the $5 \%$ level, and $* * *$ significant at the $1 \%$ level

Regarding $H$ value (the sum of price elasticity: PF, PK, PL), we find that all $H$ values in the models are less than one and greater than zero, and both hypotheses where the $H$ value is equal to unity and the $H$ value is equal to zero are rejected, indicating that commercial banks operating in the MENA economies were earning their revenues (total revenue to total assets and interest income to total assets) under monopolistic competition for the period of the study. The H-statistic for Table 3 varies between 0.73 and 0.83 for total revenues (TR/TA) and ranges between 0.86 and 0.90 for interest income, suggesting evidence of monopolistic competition. More specifically, Wald tests $H=0$ and $H=1$ for banks operating in 11 MENA economies included in the sample reject perfect and monopoly conditions of the banking industry, whilst the value of the $\mathrm{H}$-statistic is also not negative. In particular, results of the Wald tests $(H=0$ and $H=1)$ in eight out of nine tested models confirm that banks operate under monopolistic competition, providing support for hypothesis (H1) that commercial banks in the MENA region increase revenue due to monopolistic competition. Findings of the H-statistic are in line with those in other studies in MENA economies and other emerging markets (Gunalp and Celik [23]; Hauner and Peiris [29]; Turk-Ariss [7]). A monopolistic competition structure can be considered consistent with product differentiation, in spite of their main business being fairly similar.

\section{State and Foreign ownership}

To examine how state and foreign ownership affects revenues and profitability, we use state and foreign ownership dummy variables. Coefficients of foreign dummies are negative and insignificant, providing evidence that banks with foreign ownership do not generate more or less revenue than other banks. From the other side, coefficients of state dummies are positive and insignificant, providing evidence that state bank ownership does not generate more or less revenue than other banks, either with or without accounting for year and/or country effects.

These are significant findings, indicating that the policy of reducing the role of state banks and increasing foreign participation had no effect whatsoever in the area during this long period, questioning the claim that privatisation leads to a more effective banking industry. The coefficient of foreign ownership (FORE) in Tables 5, 6and 7 is 
insignificant in all but one regression, indicating that the hypothesis H2, that MENA banks are more profitable if they increase foreign ownership, does not hold. To examine the hypothesis that state ownership is associated with decreasing profitability, we examine the significance and magnitude of coefficients of state ownership (STATE). In all but one regression in Tables 6 and 7, the coefficient of state ownership is insignificant whilst in one case it is significant and positive, indicating that the hypothesis H2 does not hold, either. Such finding, not recognised by previous studies, that questions the validity of regulatory practices, forced by large transnational organisations which aim to decrease state ownership and increase foreign control of the banking sector.

Table 7 Panzar and Rosse model test using ROA as dependent Variable

\begin{tabular}{|c|c|c|c|c|}
\hline & Fixed effect 10 & Fixed effect 11 & Fixed effect 12 & Fixed effect 13 \\
\hline \multirow[t]{2}{*}{ LnPF } & -0.070 & $0.089 * *$ & $-0.15^{* * *}$ & 0.060 \\
\hline & $(-1.341)$ & $(2.233)$ & $(-3.011)$ & (1.539) \\
\hline \multirow[t]{2}{*}{ LnPK } & $0.148 * * *$ & $0.137 * * *$ & $0.171 * * *$ & $0.166^{* * *}$ \\
\hline & $(3.540)$ & $(3.231)$ & $(4.259)$ & (4.024) \\
\hline \multirow[t]{2}{*}{ LnPL } & -0.088 & $-0.128 * *$ & $-0.102 * *$ & -0.161 \\
\hline & $(-1.549)$ & $(-2.217)$ & $(-1.877)$ & $(-2.884)$ \\
\hline \multirow[t]{2}{*}{ LnSECAST } & 0.020 & 0.001 & 0.006 & -0.019 \\
\hline & $(0.712)$ & $(0.054)$ & $(0.247)$ & $(-0.720)$ \\
\hline \multirow[t]{2}{*}{ LnSIZE } & 0.019 & -0.022 & $0.114 * * *$ & $0.044^{*}$ \\
\hline & $(0.534)$ & $(-0.821)$ & (3.904) & $(1.731)$ \\
\hline \multirow[t]{2}{*}{ LnEQAS } & $0.845 * * *$ & $0.835 * * *$ & $1.000 * * *$ & $0.996 * * *$ \\
\hline & (12.005) & $(12.222)$ & (15.549) & (15.337) \\
\hline \multirow[t]{2}{*}{ LnLOANAST } & $0.172 * *$ & $0.110^{*}$ & $0.243 * * *$ & $0.216 * * *$ \\
\hline & $(2.625)$ & $(1.683)$ & (3.987) & (3.453) \\
\hline \multirow[t]{2}{*}{ FORE } & $0.209^{*}$ & 0.181 & 0.139 & 0.039 \\
\hline & $(1.793)$ & $(1.541)$ & $(1.283)$ & $(0.355)$ \\
\hline \multirow[t]{2}{*}{ STATE } & 0.070 & 0.063 & -0.066 & -0.083 \\
\hline & $(0.685)$ & $(0.612)$ & $(-0.690)$ & $(-0.838)$ \\
\hline \multirow[t]{2}{*}{ INTERCEPT } & $-3.46 * * *$ & $-2.33 * * *$ & $-5.63 * * *$ & $-4.31 * * *$ \\
\hline & $(-4.828)$ & $(-4.130)$ & $(-11.353)$ & $(-9.706)$ \\
\hline \multirow{2}{*}{\multicolumn{5}{|c|}{ EFFECTS }} \\
\hline & & & & \\
\hline \multicolumn{5}{|l|}{ COUNTRY } \\
\hline \multicolumn{5}{|l|}{ EFFECTS } \\
\hline $\mathbf{R}^{2}$ Adj & 0.54 & 0.52 & 0.53 & 0.50 \\
\hline Hausman test & 0.000 & 0.000 & 0.000 & 0.000 \\
\hline H-value & -0.01 & 0.09 & -0.08 & 0.06 \\
\hline
\end{tabular}




\begin{tabular}{ccccc}
\hline Wald test, $\mathbf{H = 0}$ & 0.017 & 1.647 & 1.131 & 0.818 \\
Prob & 0.896 & 0.199 & 0.287 & 0.365 \\
\hline
\end{tabular}

Dependent variable: $\mathrm{Ln}(\mathrm{ROA})$. $\mathrm{ROA}=$ return on average assets. Independent variable: $\mathrm{PF}=$ price of fund (interest expense to deposits), $\mathrm{PK}=$ price of capital (non-interest expenses to fixed assets, $\mathrm{PL}=$ price of labour (personal expenses to total assets), SECAST $=$ securities to total assets, SIZE $=$ Total assets, EQAS= equity to total assets, LONAAST= net loans to assets, FORE $=$ dummy for foreign ownership, STATE $=$ dummy for state ownership

*significant at the $10 \%$ level; **significant at the $5 \%$ level, and ***significant at the $1 \%$ level

\section{Firm - specific factors}

We also examine the bank-specific factors that affect revenues. The coefficient of Securities investments (SECAST) is negative and significant at $5 \%$ with TR/TA indicating that banks' securities do not contribute in terms of overall revenue in MENA economies. With respect to the Capital Adequacy (EQAS) variable, all results are positive and significant at the $10 \%$ and $5 \%$ level, implying that banks that operate in the MENA region with higher capital adequacy ratios tend to create more revenues; supporting the argument that capital adequacy is positively associated with revenues. The regression coefficient of bank size (SIZE) is negative and statistically significant when we don't account for Year effects, suggesting that size in terms of assets in MENA economies contributed to reducing revenues and implying that larger banks were, in some cases, less efficient than smaller banks. Finally Loans over Assets (LOANAST) is found to be positive and significant in all regressions indicating that banks focused in traditional loan activities, strengthen their revenues and profits compared to their peers. The positive and significant coefficient of LOANAST, in conjunction with the negative and significant coefficient of SECAST, would raise a concern that commercial banks in the MENA economies tend to concentrate on traditional lending activities, where their competitive position may be eroded in the long run by Islamic banks, confirming the findings of Olson and Zoubi [33] that Islamic banks are more revenue efficient than conventional banks because Islamic banks hold more profitable assets than the loans and securities held by conventional banks. Given that capital adequacy (EQAS) and loans (LOANAST) enhance revenues, the hypothesis $\mathrm{H} 3$ that commercial banks operating in MENA countries increase revenue due to firm-specific factors is not rejected. Such results are considered to be important to regulators, policy makers and bank managers in the MENA economies as to highlight that the growing in total assets by acquisition or mergers may not be appropriate and effective, suggesting that smaller banks can be more efficient in reducing asymmetric information problems, partly in line with findings of Turk-Ariss [7]. Finally, net loans to total assets (LOANAST), a variable that proxies liquidity (Mamatzakis et al. [10]), is statistically significant, implying that a larger proportion of loan to total assets generates more interest income and total revenues for MENA commercial banks. Overall, these findings confirm that commercial banks in MENA economies tend to focus on traditional lending activities, implying an unwillingness or inability of commercial banks to generate income from new investment opportunities. 


\section{Test for Market Equilibrium}

The validity of the Panzar and Rosse model, based on the assumption of equilibrium conditions, is tested by employing Eq. (3) and by using the Wald test to examine if null hypothesis $H=0$ holds, the latter as advocated by a number of authors (Gunalp and Celik, [23]). If rejected, then the industry is not regarded as being in an equilibrium level. Being in equilibrium does not exclude competitive positions changing later on, but rather indicates that changes in the banking sector are gradual (Mamatzakis et al. [10]). Equilibrium tests for the fixed effects models are presented in Table 7.

The suitability of the fixed effects models is verified by the Hausman test. Results also confirm that the equilibrium hypothesis, $H$ value is equal to zero, is not rejected in any of the examined regressions. Therefore, the overall findings suggest that commercial banks operating in MENA economies were under long-term equilibrium of monopolistic competition for the study period. These findings support the validity of the Panzar-Rosse model as examined in Eqs. (1) and (2), validating our findings in general, and confirming the hypothesis (H1) that commercial banks operating in MENA countries increase revenue due to monopolistic competition. This finding is in line with findings of Gunalp and Celik [23], Hauner and Peiris [29], and Turk-Ariss [7]. The paper provides evidence that the market in MENA countries is under monopolistic competition during the period that includes the global financial crisis of 2007 and the Arab Spring, and is the first of its kind for the examined period that takes account for country and year effects. In addition, this is the first study of its kind that draws conclusions about equilibrium market conditions in 11 countries of the MENA region during the period examined (19992012).

\section{Conclusion}

This paper examined the competitive conditions of MENA banks. First, our tests reject the hypothesis of perfect competition and monopoly in the banking industry in eight out of nine regressions examined and support the hypothesis of monopolistic competition during the period 1999-2012. This is the first study that examines 11 MENA countries and takes account of year and country effects as well as bank ownership status. Second, we examined whether firm-specific factors lead to increasing revenues. Capital adequacy is also found positive and statistically significant in some cases, supporting the argument that well-capitalised banks may enjoy access to cheaper and less risky sources of funds. The coefficient of Loans over Assets is positive and significant in all regressions, indicating that banks that focus on traditional loan activities tend to be more profitable. Third, we investigated whether state and foreign ownership affect performance.

Our results confirm previous findings about the existence of monopolistic competition while extending past evidence in four ways. First, the results suggest that size does not lead to more revenue per unit of assets used, implying that smaller banks can be more efficient in reducing asymmetric information problems, something that confirms TurkAriss [7], findings. Second, we found no support for the hypothesis that state banks are associated with decreasing or increasing revenues, or any support that foreign ownership 
is a significant explanatory variable for the study group and the period examined. Third, we conclude that the MENA commercial banking sector's reliance on traditional lending activities is not associated with effective use of other assets, confirming the findings of Olson and Zoubi [33] that poor asset management of these banks may lead to decreasing market position in the long run. Finally, we examined the validity of the Panzar and Rosse model by testing market equilibrium conditions and found that the equilibrium hypothesis is not rejected, providing evidence of presence of long equilibrium, in line with findings in other studies (eg. Molyneux et al. [9]; Mamatzakis et al. [10]). These findings are particularly important due to their policy implications, favouring inter alia legislation that leads to well-capitalised banks. 


\section{References}

1. Claessens, S. 2009. Competition in the financial sector: overview of competition policies. The World Bank Research Observer 24(1): 83-118.

2. Levine, R. 1997. Financial development and economic growth: Views and agenda. Journal of Economic Literature 35(2): 688-726.

3. La Porta, R., F. Lopez-de-Silanes, A. Shleifer, and R.W. Vishny. 1997. Legal determinants of external finance. Journal of Finance 52(3): 1131-1150.

4. Porta, R.L., F. Lopez-de-Silanes, A. Shleifer, and R.W. Vishny. 1998. Law and finance. Journal of Political Economy 106(6): 1113-1155.

5. González-Rodríguez, F. 2008. The relationship between charter value and bank market concentration: The influence of regulations and institutions. Applied Financial Economics 18(2): 153-172.

6. Panzar, J.C., and J.N. Rosse. 1987. Testing for "monopoly" equilibrium. The Journal of Industrial Economics 1: 443-456.

7. Turk-Ariss, R. 2009. Competitive behavior in Middle East and North Africa banking systems. The Quarterly Review of Economics and Finance 49(2): 693-710.

8. Bikker, J.A., S. Shaffer, and L. Spierdijk. 2012. Assessing competition with the Panzar-Rosse model: The role of scale, costs, and equilibrium. Review of Economics and Statistics 94(4): 1025-1044.

9. Molyneux, P., D.M. Lloyd-Williams, and J. Thornton. 1994. Competitive conditions in European banking. Journal of Banking \& Finance 18(3): 445-459.

10. Mamatzakis, E., C. Staikouras, and N. Koutsomanoli-Fillipaki. 2005. Competition and concentration in the banking sector of the South Eastern European region. Emerging Markets Review 6(2): 192-209.

11. Shleifer, A., and R.W. Vishny. 1994. Politicians and firms. The Quarterly Journal of Economics 109(4): 995-1025.

12. Shleifer, A. 1998. State versus private ownership. Journal of Economic Perspectives 12(4): 133-150.

13. Lowe, N. 2013. Modern world history. Palgrave master series. Hampshire: Macmillan.

14. Naceur, S.B., and M. Omran. 2011. The effects of bank regulations, competition, and financial reforms on banks' performance. Emerging Markets Review 12(1): 1-20.

15. Outlook, R.E. 2013. Middle East and Central Asia. World Economic and Financial Surveys. Washington, DC: International Monetary Fund (IMF).

16. Omran, M. 2007. Privatization, state ownership, and bank performance in Egypt. World Development 35(4): 714-733.

17. Naceur, S.B., H. Ben-Khedhiri, and B. Casu. 2009. What drives the efficiency of selected MENA banks? A meta-frontier analysis. Working Paper No. 499, Economic Research Forum

18. The Banking Law (120/1975). Central Bank of Egypt (2008).

19. Naceur, M.S., and M.M. Kandil. 2013. Basel capital requirements and credit crunch in the MENA region. Washington: International Monetary Fund. 
20. Bdour, J.I., and A.F. Al-khoury. 2008. Predicting change in bank efficiency in Jordan: A data envelopment analysis. Journal of Accounting \& Organizational Change 4(2): 162-181.

21. Berger, A.N. 1995. The profit-structure relationship in banking-tests of marketpower and efficient-structure hypotheses. Journal of Money, Credit and Banking27(2): 404-431.

22. Bikker, J., and J.W. Bos. 2008. Bank performance: A theoretical and empirical framework for the analysis of profitability, competition and efficiency. Abingdon: Routledge.

23. Günalp, B., and T. Çelik. 2006. Competition in the Turkish banking industry. Applied Economics 38(11): 1335-1342.

24. Nathan, A., and E.H. Neave. 1989. Competition and contestability in Canada's financial system: Empirical results. Canadian Journal of Economics 1: 576-594. 25.Molyneux, P., J. Thornton, and D.M. Llyod-Williams. 1996. Competition and market contestability in Japanese commercial banking. Journal of Economics and Business 48(1): $33-45$.

26. De Rozas, L.G. 2007. Testing for competition in the Spanish banking industry: The Panzar-Rosse approach revisited.

27. Olivero, M.P., Y. Li, and B.N. Jeon. 2011. Competition in banking and the lending channel: Evidence from bank-level data in Asia and Latin America. Journal of Banking \& Finance 35(3): 560-571.

28. Barros, C.P., and Z. Mendes. 2016. Assessing the competition in Angola's banking industry. Applied Economics 48(30): 2785-2791.

29. Hauner, D., and S.J. Peiris. 2008. Banking efficiency and competition in low income countries: the case of Uganda. Applied Economics 40(21): 2703-2720.

30. Murjan, W., and C. Ruza. 2002. The competitive nature of the Arab Middle Eastern banking markets. International Advances in Economic Research 8(4): 267-274.

31. Polemis, M.L. 2015. Does monopolistic competition exist in the MENA region? Evidence from the banking sector. Bulletin of Economic Research. 67(S1): S74-S96

32. Baltagi, B. 2008. Econometric analysis of panel data. New York: Wiley.

33. Olson, D., and T.A. Zoubi. 2011. Efficiency and bank profitability in MENA countries. Emerging Markets Review 12(2): 94-110.

34. Bikker, J.A., and K. Haaf. 2002. Competition, concentration and their relationship: An empirical analysis of the banking industry. Journal of Banking \& Finance 26(11): 2191-2214.

\section{Hatem Elfeituri ${ }^{1}$}

${ }^{1} \mathrm{PhD}$ in Accounting and Finance - University of Portsmouth, UK 2016; Lecturer in Accounting and Finance, University of East London, UK; Lecturer in Accounting, University of Benghazi, Libya; Contact details: University of East London, London, E16 2RD, UK. Email: Hatem@uel.ac.uk, H.elfeituri@gmail.com

\section{Konstantinos Vergos ${ }^{2}$}

${ }^{2} \mathrm{PhD}$ in Finance, Senior lecturer in Economic and Finance, Portsmouth Business School, University of Portsmouth, Richmond Building Portland Street Portsmouth PO1 3DE UK Email: konstantinos.vergos@port.ac.uk 